\title{
Education Systems as Contextual Factors in the Technological Pedagogical Content Knowledge Framework
}

\author{
Karolina Dobi Barišić \\ Faculty of Educational Sciences \\ University of Osijek,Croatia
}

\section{Blaženka Divjak}

Faculty of Organization and Informatics

University of Zagreb, Varaždin, Croatia

\section{Valentina Kirinić}

Faculty of Organization and Informatics

University of Zagreb, Varaždin, Croatia karolina.dobi@foozos.hr

blazenka.divjak@foi.hr

valentina.kirinic@foi.hr

\begin{abstract}
Digital competences should be considered in teacher education and professional development. The Technological Pedagogical Content Knowledge (TPACK) framework represents the knowledge required by teachers in order to successfully integrate technology into the teaching process. The Survey of Pre-service Teachers' Knowledge of Teaching and Technology (SPTKTT) is one of the inventories developed to measure the TPACK framework. The aim of this study is to validate the SPTKTT inventory in the context of the Croatian education system by the use of exploratory and confirmatory factor analysis. Results showed that the new context structure of the SPTKTT inventory consists of nine factors, while confirmatory factor analysis established that the two Content Knowledge factors can actually be unified. This can be explained by differing content organization in education systems. There were also differences in the distribution of some of the remaining factors. Internal consistency of the inventory shows high reliability.
\end{abstract}

Keywords: TPACK framework, SPTKTT inventory, validation, exploratory factor analysis, confirmatory factor analysis

\section{Introduction}

The development of education in the 21st century has displayed the importance of technology in improving the learning and teaching processes. Digital knowledge sources are now more accessible to all, and the introduction of information and communication technology (ICT) and new digital educational content requires teachers, counselors, mentors, and trainees to master the ability to introduce new approaches. Therefore, uninterrupted professional development is imperative for all 
educators and professional associates in order to aid the process of recognizing and developing the technological competencies of their students. All higher educational systems now emphasize the need for the development of digital knowledge, skills, and accountability in both students and teachers alike. Croatian educational strategies also stress that rapid technological changes create great challenges in the teaching profession, requiring profound changes in education and learning [1].

The Croatian Education and Teacher Training Agency composed a strategy for teacher training and professional development [2] that defines professional advancement as improving knowledge of the specific subject matter, as well as didactic methodology, and emphasizing the use of ICT in teachers' work and professional development. Competences in the area of education and training cover subject-specific academic and didactic-methodical knowledge, such as personalized learning outcomes. Basic teacher competences include working effectively with information and communication technologies [2].

According to the Recommendation Concerning the Status of Teachers in the Croatian education system, the term "teacher" is used for all persons responsible for teaching until the completion of secondary education, including early childhood, preschool, primary, technical, vocational, and artistic education [1].

Koehler and Mishra [3] have developed a framework of teacher knowledge for technology integration called Technological Pedagogical Content Knowledge (TPACK). The TPACK framework builds on Lee Shulman's construct of Pedagogical Content Knowledge (PCK) to include technological knowledge. It should be noted that education for the 21st century involves not only the acquisition of knowledge but, additionally, the development of skills and competences [4], [5]. By better describing the types of knowledge teachers need (in the form of content, pedagogy, technology, and their interactions) it allows teachers, researchers, and teacher educators to move beyond oversimplified approaches that treat technology as an "add-on." Instead, it focuses upon the connections among technology, content, and pedagogy as they play out in a classroom context [3]. The guidelines for progression in the TPACK theoretical framework relate to the further development of instruments, as well as the validation of existing ones, while being increasingly diverse in focus and method [6].

Schmidt et al. [7] created the inventory for measuring TPACK, named the Survey of Pre-service Teachers' Knowledge of Teaching and Technology (SPTKTT). The authors of the instrument [7] carried out an exploratory factor analysis and confirmed the theoretical structure with high factor loadings and Cronbach alpha coefficients. However, Chai et al. [8] criticized their method for determining the factor structure of the questionnaire [8], which highlights the need for further empirical research on this measurement tool and its applications [9].

It should be noted that most quantitative studies have been conducted by Asiansituated research groups. The TPACK surveys need to be validated in other contexts to check for cultural differences [10]. Context is an important aspect of both educational research and the TPACK theoretical framework, but it is often omitted in TPACK research, or its meaning is not clearly indicated [11].

The Croatian education system is divided into four categories. There is first preschool education, implemented in kindergartens and preschool institutions. The 
second is elementary education, beginning with enrollment into the first grade. It is compulsory for all children, and in general, it begins at the age of six and lasts for eight years. It is divided into two stages: grades one to four, when the students generally have one teacher, and grades five to eight, when students change teachers for each subject. Subjects areas covered in grades one to four are Croatian language, Mathematics, Nature and Society, Visual and Music Art, and Physical Education. The third education category is secondary education. After completing elementary school, students have the opportunity to continue their education voluntarily in secondary schools. They are, depending on the type of educational program, divided into high schools, vocational schools, and artistic secondary schools. State graduation exams are obligatory for high school students, but may be taken by students of other schools as well. The final category is higher education, where students are enrolled at the desired institution on the basis of their State graduation exam results [12].

Though education in the United States may vary some at the state level, it is generally organized into three principal categories. The first is elementary school, which is compulsory and begins at the age of five or six in most states and lasts to 12 or 14 years of age. Subject areas learned at this educational stage are Language Arts, Mathematics, Social Studies/Citizenship, Science, Visual and Music Arts, and Physical Education. Secondary school begins at the fourth or ninth grade, depending on the duration of the previous education level, and leads to the high school diploma. Higher education, the final category, is diverse. High school graduates who decide to continue their education may enter a technical or vocational institutions, a two-year college, or a four-year college or university [13].

Due to the distinctions within the educational systems, particularly concerning the subject areas studied at the elementary stage, factor analysis was conducted to determine possible differences in factor structure.

This research validates the SPTKTT inventory carried out by exploratory and confirmatory factor analysis in the Croatian education system context and aims to address the following questions:

1. What factors of the TPACK are perceived by Croatian students of primary education study programs (pre-service teachers) when the SPTKTT inventory is being used?

2. Do differences in educational systems affect the factor structure of the TPACK framework measured by the SPTKTT inventory?

\section{Technological Pedagogical Content Knowledge Framework}

As noted above, Koehler and Mishra's TPACK model emphasizes technological knowledge, building Lee Shulman's construct of PCK. The model consists of three main components of teachers' knowledge: Content (CK), Pedagogy (PK), and Technology (TK). Equally important to the model are the interactions between and among these bodies of knowledge, represented as: PCK (Pedagogical Content Knowledge), TCK (Technological Content Knowledge), TPK (Technological Pedagogical Knowledge), and TPACK (Technological Pedagogical Content Knowledge), as shown in Figure 1. The interaction of these bodies of knowledge, both 
theoretically and in practice, produces the types of flexible knowledge needed to successfully integrate technology into teaching [3].

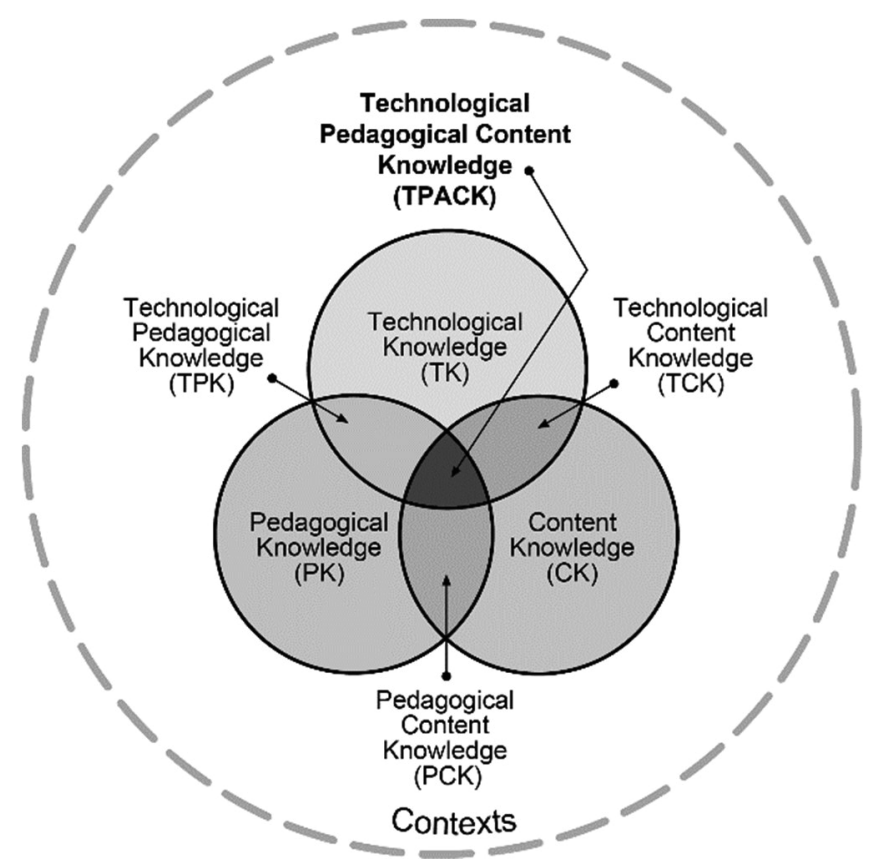

Figure 1. The TPACK framework (reproduced by permission of the publisher, (C) 2012 by tpack.org)

Koehler and Mishra [3] explained each of the domains and their intersection in the following way:

- Content knowledge (CK) is teachers' understanding concerning the subject matter to be learned or taught, and it is of critical importance. This knowledge includes concepts, theories, ideas, organizational frameworks, evidence, and proof, as well as established practices and approaches for instruction concerning the topic. It is pivotal that educators understand the deeper fundamentals of the disciplines that they teach.

- Pedagogical knowledge (PK) is teachers' understanding concerning the processes, practices, and methods of teaching and learning. This form of knowledge applies to understanding how students learn, general classroom management skills, lesson planning, and student assessment. A teacher with in-depth pedagogical knowledge understands how students learn, what is required for skill acquisition, and ways to ensure the development of good mental habits and a positive disposition toward learning.

- Pedagogical Content Knowledge (PCK) is similar to Shulman's idea of pedagogy, in that it is applicable to the teaching of specific content. In this context, the notion of the "transformation" of a subject matter for teaching is very important. This transformation occurs as the teacher interprets the topic, 
finds multiple ways to represent it, and adapts and tailors the instructional materials to alternative concepts and students' prior knowledge.

- Technology Knowledge (TK), due to its nature, is difficult to define without the danger of that definition becoming outdated. According to the TPACK framework, this kind of knowledge requires a broad understanding of information technology, with the ability to apply it productively at work and in daily life, recognize when it can assist or impede the achievement of a goal, and continually adapt to its changes.

- Technological Content Knowledge (TCK) is an understanding of how technology and content influence and constrain one another. Teachers need to master more than the subject matter they teach; they must also have an indepth understanding of the manner in which the topic can be changed by the application of particular technologies. Teachers need to understand which specific technologies are best suited for addressing subject-matter learning in their domains.

- Technological Pedagogical Knowledge (TPK) is an understanding of how teaching and learning can change when technologies are used in specific ways. TPK is particularly important because most popular software programs are not designed with education in mind. Teachers need to develop skills to look beyond common uses for technologies, reconfiguring them for customized pedagogical purposes. Thus, TPK requires an innovative and open-minded use of technology for the sake of advancing student learning.

- Technological Pedagogical Content Knowledge (TPACK) is an understanding that emerges from interactions among content, pedagogy, and technology knowledge, building upon an understanding of all three individual concepts. TPACK is the basis of truly effective and skilled teaching with technology, requiring an understanding of the concepts that utilize it. It encompasses pedagogical techniques that use technologies in constructive ways to teach content; an understanding of how to integrate technology to address possible learning difficulties; an assessment of students' prior knowledge and theories of epistemology; and the ability to use technologies to build on existing knowledge, developing new methods or strengthening previous ones.

The TPACK highlights knowledge transformation. Teachers rely on it when designing and implementing curriculum to guide learning with digital technologies in various content areas [14].

\section{Literature Review}

The most significant contributions of the TPACK framework are in the field of teacher education and continuous professional development.

The instructional techniques and other factors that influence the development of technological knowledge have been investigated in recent literature. Learning by design appears to be an effective instructional technique to develop a deeper 
understanding of the complex web of relationships between content, pedagogy, technology, and the contexts in which they function [15].

According to Kushner, Benson, Ward, and Liang [16, p. 16], it is clear that technology cannot be considered an isolated solution for transforming education. Their research supports the premise that PK and TPK are key factors to the development of TPACK, even more so than extensive technology skills training. Professional development focused solely on the development of technology knowledge will not lead to effective integration. If narrow technology training is carried out in order to successfully integrate it into the teaching process and these initiatives fail, most look to the technology as the point of breakdown. However, it is usually the absence of pedagogical, content, or implementation strategies that leads to the lack of perceived success. Since the TPACK framework is pedagogically free [17], it is important that TPACK-based professional development for teachers is flexible and inclusive enough to accommodate the full range of teaching philosophies, styles, and approaches [18].

One of the significant limitations of the TPACK framework is that it is neutral with respect to the broader goals of education. For instance, the TPACK framework does not address what kind of content needs to be covered and how it should be taught [19]. Hence, the TPACK framework can be used for different pedagogical approaches [17]. Koehler et al. [19, p. 109] emphasized the need for development in the area of measuring how TPACK works in different disciplinary contexts, while Valtonen et al. [17] distinguished two main challenges related to the available instruments; namely, psychometric features and the nature of pedagogical knowledge. Several TPACK measurement instruments have been developed. Their factor structure had been determined, and ten of them are shown in Table 1.

Despite the construct validity of the TPACK framework being established, Drummond and Sweeny [20] wanted to explore whether the self-reported knowledge assessed by the TPACK scales might be supplemented by pre-service teachers' objective knowledge in sub-areas of TPACK. After completing the TPACK-deep survey [21], a series of statements about technology use for teaching was rated on a six-point scale, with one indicating certainty that the statement is false and six indicating certainty that the statement is true. The results suggest that the subjective knowledge assessed by the TPACK scale (TPACK-deep) could be supplemented by the inclusion of objective indices of technological pedagogical and content knowledge to form a more complete picture of pre-service teachers' TPACK.

Rosenberg and Koehler [11] note that some researchers have used TPACK measurements to confirm the proposed TPACK framework structure with seven domains, as represented in Fig. 1, while others have found support for fewer components. Different studies resulted in various numbers of factors extracted during the exploratory factor analysis: three [22], [23]; four [24]; five [8], [25], [26], [27]; six [17]; seven [7], [28]; eight [29]; and nine [10] (Table 1). A problem often encountered in the TPACK survey research is the merging of factors during statistical analyses for construct validation [10].

The authors of the SPTKTT inventory [7] conducted an exploratory factor analysis over the inventory items and confirmed the factor structure with high factor 
loadings and Cronbach $\alpha$ coefficient values. Validation of the SPTKTT has been questioned because the process of validation was conducted separately for each of the seven domains of TPACK [8].

\begin{tabular}{|c|c|c|c|}
\hline Study & $\begin{array}{c}\text { Number of } \\
\text { items }\end{array}$ & Participants (context) & $\begin{array}{c}\text { Number of } \\
\text { factors }\end{array}$ \\
\hline $\begin{array}{c}\text { (Schmidt et al., } \\
\text { 2009) }\end{array}$ & 47 & Undergraduate students & 7 \\
\hline $\begin{array}{c}\text { (Archambault \& } \\
\text { Barnett, 2010) }\end{array}$ & 24 & Online teachers & 3 \\
\hline (Chai et al., 2010) & 18 & Singaporean preservice teachers & 4 \\
\hline (Lee \& Tsai, 2010) & 30 & $\begin{array}{c}\text { Self-efficacy of Taiwanese } \\
\text { teachers for web-based learning }\end{array}$ & 5 \\
\hline (Chai et al., 2011) & 46 & $\begin{array}{c}\text { Singaporean preservice teachers } \\
\text { (ICT for meaningful learning) }\end{array}$ & 5 \\
\hline (Pamuk et al., 2015) & 37 & $\begin{array}{c}\text { Preservice teachers } \\
\text { foreign language) }\end{array}$ & 7 \\
\hline (Baser et al., 2015) & 39 & $\begin{array}{c}\text { Preservice teachers (English as } \\
\text { fores }\end{array}$ & 5 \\
\hline $\begin{array}{c}\text { (Valtonen et al., } \\
\text { 2015) }\end{array}$ & 36 & $\begin{array}{c}\text { Preservice teachers (ICT in the } \\
\text { context of 21st century skills) }\end{array}$ & 6 \\
\hline $\begin{array}{c}\text { (Ritzhaupt et al., } \\
\text { 2016) }\end{array}$ & 47 & $\begin{array}{c}\text { Preservice elementary school } \\
\text { teachers }\end{array}$ & 9 \\
\hline (Luik et al., 2018) & 56 & Estonian preservice teachers & 3 \\
\hline
\end{tabular}

Table 1. Measurement instruments developed on the base of TPACK framework

Ritzhaupt et al. [9] also carried out the validation of the SPTKTT questionnaire and found that there is no clear difference between the Pedagogical Knowledge, Pedagogical Content Knowledge, Technological Pedagogical Knowledge, and Technological Pedagogical Content Knowledge. These four subscales collapsed into three unintended latent factors, one of which is composed of items from Pedagogical Knowledge and Pedagogical Content Knowledge, while another includes items from Technological Pedagogical Knowledge, Technological Pedagogical Content Knowledge, Technology Knowledge, Social Science Content Knowledge, Science Content Knowledge, Literacy Content Knowledge, Mathematics Content Knowledge, and Technological Content Knowledge.

Pamuk et. al. [28] confirmed the structure of the seven factors of the SPTKTT questionnaire. They suggested that further research studies carried out with the proposed instrument in different contexts would be helpful in terms of not only validating the instrument but also discussing the findings. 


\section{Methodology}

\subsection{Sample}

The data necessary to validate the inventory were collected during the 2015/16 academic year at five higher education institutions in the Republic of Croatia (Faculty of Educational Sciences in Osijek and Slavonski Brod, Faculty of Teacher Education in Zagreb and Čakovec, and Faculty of Humanities and Social Sciences in Osijek). The sample consisted of 337 students and was collected through different study programs that educate future preschool teachers $(\mathrm{N}=21)$, first through fourth grade primary school teachers $(\mathrm{N}=301)$, and fifth through eighth grade primary school teachers $(\mathrm{N}=15)$. The survey was collected on the undergraduate and graduate level and includes all study years.

The most suitable sample size for factor analysis is not unanimously defined, and there is a wide range of proposals on the subject. Sample size requirements are decreasing over the years as the amount of research on a particular subject increases ([30, p. 372]). Some of the rules are as follows:

- The recommendations for minimal sample size $\mathrm{N}$ range from a minimum of 100 to 500 or even 1000 data. Kline [31, p. 73] states that a sample of 100 is quite sufficient for data with a clear factor structure, and if the sample is smaller than that, the results obtained should be confirmed in other samples.

- The recommendations for the minimum ratio of the sample size $\mathrm{N}$ and the number of observed variables $\mathrm{p}$ range from 10:1 up to 2:1, where Kline [31, p. 74] states that significant factors can clearly be extracted with the sample that was observed at $2: 1$.

- The minimum sample size ratio $\mathrm{N}$ and the number of extracted factors should be at least 20:1 [31].

- Lawley and Maxwell [32] suggest that the sample size should be higher than the number of variables by 51 .

All of the sample size recommendations above are fulfilled with the sample used in this study.

\subsection{Measurement Instrument}

The Survey of Preservice Teachers' Knowledge of Teaching and Technology [7] is a 47-item Likert type scale survey with items (T1 - 47) that includes 10 subscale measures for each TPACK domain, including four subscales for different areas of content knowledge (Literacy, Social Studies, Mathematics, and Science) (Appendix A). Participants rated their agreement with each item on a 5-point Likert type scale (5 = strongly agree, $4=$ agree, $3=$ neutral, 2 = disagree, $1=$ strongly disagree). The measure of TPACK domains used in this study represents participants' selfassessment of their knowledge. Schmidt et al. described the development and validation of this instrument and reported Cronbach's $\alpha$ coefficients for the subscales ranging from .75 to .92 . The survey was developed specifically for use with students of the primary and/or early childhood education (pre-service teachers). It included 
multiple subscales to assess perceived content knowledge in all areas that the students would potentially be teaching in their future classrooms, including Mathematics, Science, Social Studies, and Literacy [33].

The SPTKTT focuses on very general pedagogical themes [17] and was used in this research because of the generic nature of the items, since the sample consists of students of elementary and/or early childhood education attending different study programs and courses.

The original SPTKTT inventory was written in English. For the research presented here, it was translated into Croatian using the double-translation method and was proof-read.

\section{Inventory Validation}

\subsection{Exploratory Factor Analysis}

Considering the variations in the Croatian and American education systems, an exploratory factor analysis (EFA) was conducted to find out potential differences in factor structure. The exploratory factor analysis was carried out on the basis of all 47 items.

According to Norman [34], parametric statistics can be applied to data obtained on a Likert scale, regardless of a small sample or a distribution that is abnormal or contains uneven variance.

In the course of factor extraction, a principal components analysis was used, as well as varimax normalized rotation for the purpose of an easier dimension interpretation. In order to determine the number of factors, a Kaiser criterion of eigenvalues $>1$ was used [35]. The usage of Kaiser criterion resulted in the extraction of nine factors which explain $67.9 \%$ of the variance (Table 2 ).

For the data interpretation, only factor loadings higher than 0.32 were considered [36, p. 654]. Table 3 shows factor loadings for each item in relation to nine factors after applying varimax normalized rotation.

\begin{tabular}{|l|r|r|r|r|}
\hline \multirow{2}{*}{ Value } & \multicolumn{4}{|l|}{$\begin{array}{l}\text { Eigenvalues } \\
\text { Extraction: Principal components }\end{array}$} \\
\cline { 2 - 5 } & Eigenvalue & $\begin{array}{c}\text { \% Total } \\
\text { variance }\end{array}$ & $\begin{array}{c}\text { Cumulative } \\
\text { Eigenvalue }\end{array}$ & $\begin{array}{c}\text { Cumulative } \\
\%\end{array}$ \\
\hline 1 & 14.63774 & 31.14413 & 14.63774 & 31.14413 \\
\hline 2 & 3.74684 & 7.97200 & 18.38458 & 39.11614 \\
\hline 3 & 3.00906 & 6.40226 & 21.39365 & 45.51840 \\
\hline 4 & 2.47808 & 5.27251 & 23.87173 & 50.79091 \\
\hline 5 & 2.24728 & 4.78144 & 26.11900 & 55.57235 \\
\hline 6 & 1.84774 & 3.93136 & 27.96674 & 59.50371 \\
\hline 7 & 1.45155 & 3.08841 & 29.41830 & 62.59213 \\
\hline 8 & 1.32473 & 2.81857 & 30.74303 & 65.41070 \\
\hline 9 & 1.18564 & 2.52264 & 31.92867 & 67.93333 \\
\hline
\end{tabular}

Table 2. Eigenvalues and variances for each factor of the SPTKTT inventory extracted on the base of Kaiser criterion (eigenvalues $>1$ ) 


\begin{tabular}{|c|c|c|c|c|c|c|c|c|c|}
\hline \multirow[t]{2}{*}{ Var. } & \multicolumn{9}{|c|}{$\begin{array}{l}\text { Factor Loadings (Varimax normalized), } \\
\text { Extraction: Principal components (Marked loadings are }>.32 \text { ) }\end{array}$} \\
\hline & Factor1 & Factor2 & Factor3 & Factor4 & Factor5 & Factor6 & Factor7 & Factor8 & Factor9 \\
\hline T1 & 0.1730 & 0.1317 & & 0.6675 & & & & & \\
\hline $\mathrm{T} 2$ & & & & & & & & 0.0637 & \\
\hline T3 & 0616 & -0.0055 & 1119 & 0.8003 & 0.0501 & 0.0097 & 0.0625 & 0.1651 & 0.0450 \\
\hline T4 & 0383 & -0.0058 & 1181 & 0.7763 & -0.1590 & 0.1060 & & 0.0107 & 0.2092 \\
\hline T5 & 0518 & 0.0352 & .0778 & 0.7797 & -0.0674 & 0.2166 & 0.1316 & 0.0983 & 0.1343 \\
\hline T6 & 0542 & .1033 & .0273 & 0.6988 & 0.1732 & 0.1058 & 0.1444 & 0.0141 & \\
\hline T7 & 2059 & 0.0420 & 0.0182 & 0.5909 & 0.1377 & 0.1134 & -0.0053 & 0.0762 & \\
\hline T8 & 0.0964 & $\mathbf{0 . 8 5 3 7}$ & & 0.0835 & & 0.0802 & & -0.0026 & -0.0217 \\
\hline T9 & 0.0633 & 0.8793 & & & & & & & -0.0222 \\
\hline T10 & 0.0532 & 0.7425 & -0.0046 & & & & & & \\
\hline T11 & & & & & & & & & \\
\hline T12 & & -0.0464 & & & & & & & \\
\hline T13 & & & & & & & & & \\
\hline T14 & & & & & & & & & \\
\hline T15 & & & & & & & & & \\
\hline T16 & & & & & & & & & \\
\hline T17 & & & & & & & & & \\
\hline T18 & & & & & & & & & \\
\hline T19 & & & & & & & & & \\
\hline T20 & & & & & & & & & \\
\hline T21 & & & & & & & & & \\
\hline T22 & & & & & & & & & \\
\hline T23 & & & & & & & & & \\
\hline T24 & & & & & & & & 760 & \\
\hline T25 & & & & & & & & & \\
\hline T26 & & & & & & & & & \\
\hline T27 & & & & & & & & & \\
\hline T28 & & & & & & & & & \\
\hline T29 & & & & & & & & & \\
\hline T30 & & & & & & & & & \\
\hline T31 & & & & & & & & & \\
\hline T32 & & & & & & & & 0.6485 & \\
\hline T33 & & & & & & & & 0.6944 & \\
\hline T34 & & & & & & & & 0.6585 & \\
\hline T35 & 0.3969 & & & & & & 0.4097 & 0.3842 & 962 \\
\hline T36 & & & & & & 0.0071 & 0.4467 & 0.3843 & 077 \\
\hline T37 & & & & & & -0.0694 & & 0.1334 & \\
\hline T38 & & & & & & & & -0.0319 & 0.1279 \\
\hline T39 & 0.2822 & 0.0494 & & & & 0.0984 & & 0.1395 & 0.0385 \\
\hline T40 & 0.4109 & 0.0414 & & & & -0.0116 & 0.6467 & 0.2388 & -0.0490 \\
\hline T41 & 0.4310 & -0.0197 & & & & 0.0507 & & 0.1263 & -0.0142 \\
\hline T42 & 0.3901 & & & 0.2591 & 0.0995 & 0.1455 & & 0.1123 & \\
\hline T43 & 0.4623 & & & 0.2224 & & -0.0331 & & 0.2242 & \\
\hline T44 & 0.6996 & 0.2890 & & 0.1307 & -0.0789 & 0.0303 & & 0.2193 & 0.0777 \\
\hline T45 & 0.7892 & -0.0216 & & 0.0993 & 0.1443 & 0.0753 & 0.1759 & 0.1743 & 0.1755 \\
\hline T46 & 0.7627 & -0.0089 & & 0.1093 & & 0.1605 & & 0.1625 & 0.2590 \\
\hline T47 & 0.7339 & 0.1506 & 0.1586 & 0.1092 & 0.0086 & 0.1531 & 0.1708 & 0.2487 & 0.0734 \\
\hline
\end{tabular}

Table 3. Factor loadings for all items of SPTKTT inventory after varimax normalized rotation 
Items T1-T7 (Technological Knowledge), T20-T26 (Pedagogical Knowledge), T27-T30 (Pedagogical Content Knowledge) and T31-T34 (Technological Content Knowledge) were distributed in the same way as in the EFA that was conducted by the authors of the inventory. Items T8-T19 were distributed among three factors, varying from the inventory authors' EFA, where these items were loaded into four factors. Items T35-T43 were loaded into one factor (Technological Pedagogical Knowledge), as well as items T44-T47 (Technological Pedagogical Content Knowledge). Items T40-T43 were also loaded into the Technological Pedagogical Content Knowledge factor but with lower factor loadings.

\subsection{Confirmatory Factor Analysis}

Confirmatory factor analysis was carried out with the help of the structural equation modelling software LISREL 9.2.

There are different fit indices that indicate a good fit between the theoretical model and empirical data. A review by McDonald and Ho [37] states that the most frequently cited fit indices are the comparative fit index (CFI), goodness of fit index (GFI), normed fit index (NFI), and nonnormed fit index (NNFI). Although GFI is one of the most frequently cited fit indices, research has indicated its inconsistency. Combining a large number of degrees of freedom (df) regarding the sample size, the GFI yields lower values [38], whereas its value goes up with bigger samples [39].

In order to confirm a good fit between the model and the data, $\mathrm{Hu}$ and Bentler [40] suggest a combination of two indices, one of which is always standardized root mean square residual (SRMR) $(\leq 0,09)$, and the other NNFI $(\geq 0,96)$, $)$, root mean square error of approximation (RMSEA) $(\leq 0,06)$, or CFI $(\geq 0,96)$. Kline [41] states that one should be sure to include the Chi-Square test $(\chi 2)$, RMSEA, CFI, and SRMR when citing fit indices. In addition to these, Hooper and his associates [42] suggest citing degrees of freedom (df) and the p-value, along with RMSEA, its confidence interval, and the parsimonious normed fit index (PNFI), because stated indices are the least sensitive to the size of the sample, nonspecificity of the model, and estimation parameters.

After the confirmatory factor analysis had been carried out, modification indices suggested the addition of error covariance among certain variables in order to improve fit indices (Figure 2). Only error covariance among variables belonging to the same factor was taken into account. These changes helped to improve the fit indices.

Correlations between subscales of the SPTKTT inventory suggest that the most significant overlapping occurs between the PK and PCK -0.829 ; TCK and TPK 0.720; TPK and TPACK - 0.714 (Table 4).

The fit indices of model and empirical data are the following: $\chi 2=2117.1, \mathrm{p}=$ $0.0000, \mathrm{df}=994, \chi 2 / \mathrm{df}=2.13, \mathrm{RMSEA}=0.0579$ with confidence interval $(0.0545$; $0.0613), \mathrm{SRMR}=0.0591, \mathrm{CFI}=0.889, \mathrm{PNFI}=0.745$.

Regarding RMSEA $\leq 0.06$ and $\mathrm{SRMR} \leq 0.09$, according to $\mathrm{Hu}$ and Bentler [40], these empirical data fit well into the proposed factor structure through which this model was confirmed. 


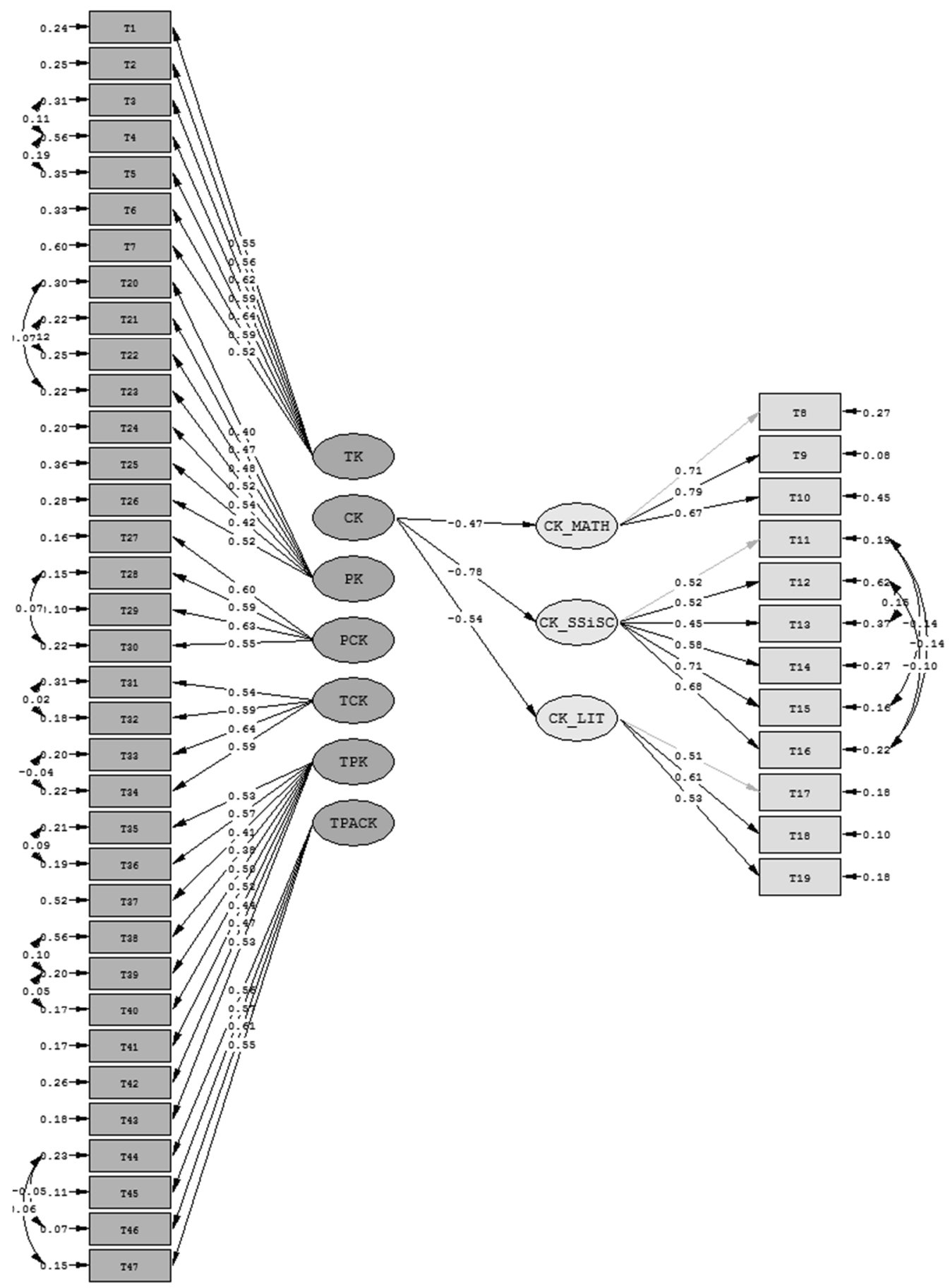

Chi-3quare $=2117.04$, df $=994, P-v a l u e=0.00000$, RMsEA $=0.058$

Figure 2. Confirmatory factor analysis of the SPTKTT inventory 


\begin{tabular}{|c|c|c|c|c|c|c|c|}
\hline $\begin{array}{c}\text { Subscales } \\
\qquad \rightarrow\end{array}$ & $\vec{\lambda}$ & $\frac{\Omega}{\pi}$ & $\bar{\pi}$ & $\tilde{\pi}$ & $\overrightarrow{\hat{\pi}}$ & $\overrightarrow{7}$ & $\frac{7}{2}$ \\
\hline TK & 1.000 & & & & & & \\
\hline CK & $\begin{array}{c}-0.576 \\
(0.055)\end{array}$ & 1.000 & & & & & \\
\hline PK & $\begin{array}{c}0.299 \\
(0.056)\end{array}$ & $\begin{array}{l}-0.437 \\
(0.063)\end{array}$ & 1.000 & & & & \\
\hline PCK & $\begin{array}{c}0.374 \\
(0.054)\end{array}$ & $\begin{array}{l}-0.605 \\
(0.053)\end{array}$ & $\begin{array}{c}0.829 \\
(0.027)\end{array}$ & 1.000 & & & \\
\hline TCK & $\begin{array}{c}0.453 \\
(0.051)\end{array}$ & $\begin{array}{l}-0.595 \\
(0.056)\end{array}$ & $\begin{array}{c}0.517 \\
(0.049)\end{array}$ & $\begin{array}{c}0.597 \\
(0.042)\end{array}$ & 1.000 & & \\
\hline TPK & $\begin{array}{c}0.526 \\
(0.046)\end{array}$ & $\begin{array}{l}-0.474 \\
(0.064)\end{array}$ & $\begin{array}{c}0.615 \\
(0.043)\end{array}$ & $\begin{array}{c}0.612 \\
(0.040)\end{array}$ & $\begin{array}{c}0.720 \\
(0.034)\end{array}$ & 1.000 & \\
\hline TPACK & $\begin{array}{c}0.367 \\
(0.053)\end{array}$ & $\begin{array}{l}-0.415 \\
(0.061)\end{array}$ & $\begin{array}{c}0.526 \\
(0.047)\end{array}$ & $\begin{array}{c}0.597 \\
(0.038)\end{array}$ & $\begin{array}{c}0.647 \\
(0.036)\end{array}$ & $\begin{array}{c}0.714 \\
(0.032)\end{array}$ & 1.000 \\
\hline
\end{tabular}

Table 4. Correlation matrix among sub-scales of the SPTKTT inventory

\subsection{Reliability}

Internal consistency is represented by the use of Cronbach $\alpha$ coefficient in relation to the items and dimensions of the inventory. Table 5 represents the Cronbach $\alpha$ coefficients for the entire inventory, including items and the subscale. Cronbach $\alpha$ coefficients are greater than $0.9(0.9093-0.9328)$ for observed items, the subscale, and the overall scale, which suggests high reliability of the SPTKTT inventory.

\section{Discussion and Conclusion}

The main aim of the research presented in this paper is to validate the SPTKTT inventory in the context of the Croatian educational system by the use of exploratory and confirmatory factor analysis.

In order to answer research question one (as stated in the introduction), an exploratory factor analysis was carried out on the subscales and items of the SPTKTT inventory, indicating the structure of the nine factors which are: Technological Knowledge, Content Knowledge (Literacy, Science and Social Sciences unified, Mathematics), Pedagogical Knowledge, Pedagogical Content Knowledge, Technological Content Knowledge, Technological Pedagogical Knowledge and Technological Pedagogical Content Knowledge. The first seven items of the questionnaire (T1-T7) were distributed in one factor, as in the exploratory factor analysis conducted by the authors of the questionnaire (Technological Knowledge). Also, the T20-T26 (Pedagogical Knowledge), T27-T30 (Pedagogical Content Knowledge), and T31-T34 (Technological Content Knowledge) were deployed [7]. There was a difference in the distribution of the items that the original questionnaire covered under Content Knowledge, Technological Pedagogical Knowledge, and Technological Pedagogical Content Knowledge. Items T35-T43 were deployed within one factor (Technological 
Pedagogical Knowledge), while items T44-T47 were deployed within another factor (Technological Pedagogical Content Knowledge).

\begin{tabular}{|c|c|c|c|c|c|}
\hline \multicolumn{6}{|c|}{$\begin{array}{l}\text { Summary for scale: } \text { Mean }=400.033 \text { Std.Dv. }=45.4299 \mathrm{~V} \\
\text { Cronbach alpha: } .914616 \text {, Standardized alpha: } .962836 \\
\text { Average inter-item corr.: } .327970\end{array}$} \\
\hline Item & Cronbach $\alpha$ & Item & Cronbach $\alpha$ & Item & Cronbach $\alpha$ \\
\hline TK & 0.912583 & CK_L & 0.912016 & T33 & 0.912860 \\
\hline $\mathrm{T} 1$ & 0.913374 & T17 & 0.913721 & T34 & 0.913208 \\
\hline $\mathrm{T} 2$ & 0.913569 & T18 & 0.913618 & TPK & 0.910043 \\
\hline $\mathrm{T} 3$ & 0.913550 & T19 & 0.913585 & $\mathrm{~T} 35$ & 0.913174 \\
\hline $\mathrm{T} 4$ & 0.913513 & PK & 0.911001 & $\mathrm{~T} 36$ & 0.913036 \\
\hline T5 & 0.913167 & $\mathrm{~T} 20$ & 0.913799 & $\mathrm{~T} 37$ & 0.913743 \\
\hline T6 & 0.913431 & $\mathrm{~T} 21$ & 0.913640 & T38 & 0.913561 \\
\hline $\mathrm{T} 7$ & 0.913362 & T22 & 0.913692 & T39 & 0.913254 \\
\hline CK & 0.932824 & T23 & 0.913598 & $\mathrm{~T} 40$ & 0.913430 \\
\hline CK_M & 0.912368 & T24 & 0.913369 & T41 & 0.913580 \\
\hline $\mathrm{T} 8$ & 0.913621 & $\mathrm{~T} 25$ & 0.913779 & T42 & 0.913228 \\
\hline T9 & 0.913599 & T26 & 0.913311 & T43 & 0.913308 \\
\hline $\mathrm{T} 10$ & 0.913336 & PCK & 0.909429 & TPACK & 0.910259 \\
\hline CK_SSiS & 0.909396 & T27 & 0.913032 & T44 & 0.913253 \\
\hline T11 & 0.913422 & $\mathrm{~T} 28$ & 0.913056 & $\mathrm{~T} 45$ & 0.913342 \\
\hline $\mathrm{T} 12$ & 0.913344 & T29 & 0.912819 & $\mathrm{~T} 46$ & 0.913215 \\
\hline $\mathrm{T} 13$ & 0.913388 & $\mathrm{~T} 30$ & 0.913149 & $\mathrm{~T} 47$ & 0.913241 \\
\hline T14 & 0.913145 & TCK & 0.909722 & & \\
\hline $\mathrm{T} 15$ & 0.912925 & T31 & 0.913266 & & \\
\hline T16 & 0.913038 & T32 & 0.913115 & & \\
\hline
\end{tabular}

Table 5. Cronbach $\alpha$ coefficients for every item, sub-scale and entire inventory

The exploratory factor analysis confirmed that items T35-T39 are deployed within theTechnological Pedagogical Knowledge factor and items T40-T47 within the Technological Pedagogical Content Knowledge factor. In this research, items T40T43 were located within Technological Pedagogical Knowledge; they were also loaded within the Technological Pedagogical Content Knowledge factor but with lower factor loads. These results are very close to the results of the exploratory factor analysis of the SPTKTT questionnaire conducted by Ritzhaupt et al. [9], where all items that represent Technological Pedagogical Knowledge and some items that represent Technological Pedagogical Content Knowledge were loaded into the same factor. This points to a deficiency in the questionnaire structure, particularly regarding items that should represent the Technological Pedagogical Knowledge and Technological Pedagogical Content Knowledge domains.

In order to answer to research question two, the variation in the factor structure among this research and that conducted by Schmidt et al. [7] can be explained by the different organization of content within the subjects in American and Croatian schools. The T8-T19 items were deployed within three factors, unlike the exploratory 
factor analysis conducted by the authors of the questionnaire, where they were deployed within four factors. The rationale for such a different factor structure probably lies in the differences in the education systems the respondents attend. In the USA, school subjects, according to their content, are Mathematics, Science, Social Sciences, and Literacy, while in Croatia, they are Mathematics and Literacy (named Croatian Language), and Social Sciences and Science are combined into one subject (named Nature and Society). Therefore, it is understandable that the items of Social Sciences Content Knowledge and Science Content fall under one factor.

Confirmatory factor analysis validated the empirical data and theoretical model. The reliability of the SPTKTT inventory was shown using Cronbach $\alpha$ coefficient. The results indicate a high level of reliability for all subscales and items of the inventory, which corresponds with existing results [7].

Possible limitations of the research can be observed in the form of an inventory that represents self-reported measures and a sample that is not representative. There is also a strong indication that the theoretical framework may not fit different education systems. Though it does have practical value, since the instrument is content neutral, it may be challenging to organize its generic items into concrete domains and evaluate knowledge that is not solely self-reported.

Future research related to this issue should include the development of an instrument that is not based only on self-assessment measures. Such an instrument should be able to objectively determine the level of knowledge that teachers have in applying technology to education. Since the method used in this research is a selfreporting measure, it would be interesting to explore how an instrument that objectively examines the teacher's knowledge of applying technology correlates with that of a self-assessment.

\section{Acknowledgements}

This work has been partly supported by the Croatian Science Foundation under the project Higher Decision IP-2014-09-7854.

\section{Appendix A: Survey of Preservice Teachers' Knowledge of Teaching and Technology}

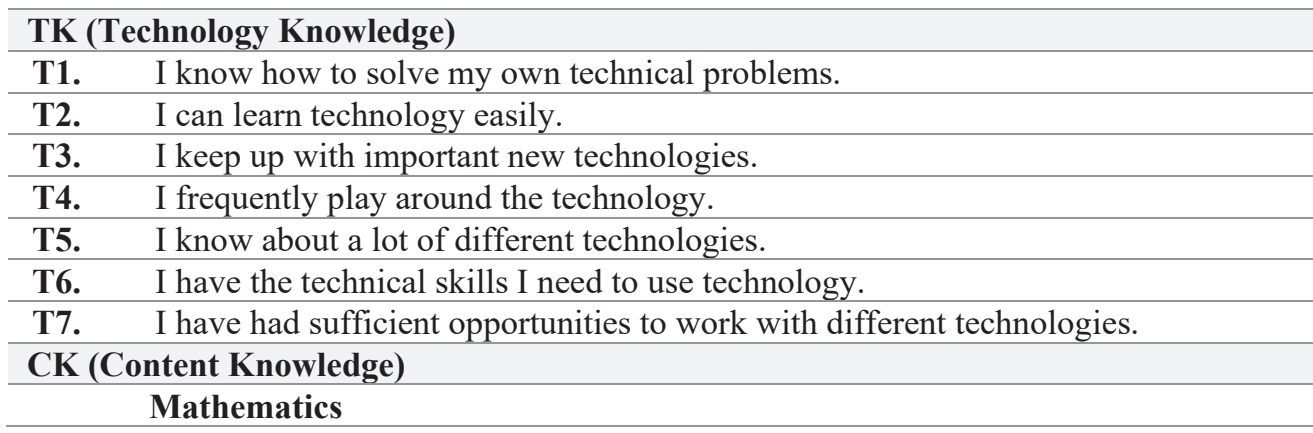




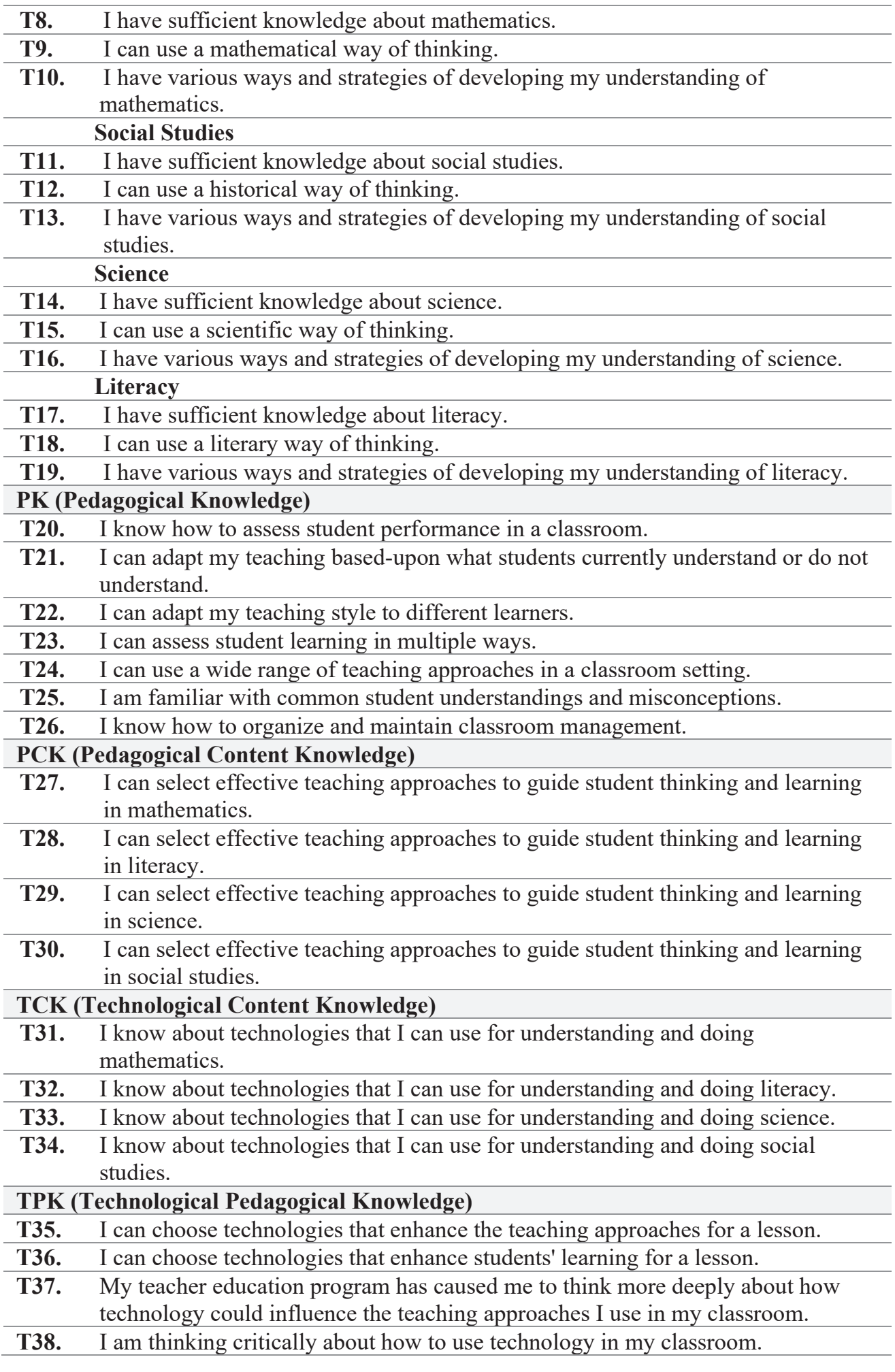




\begin{tabular}{|c|c|}
\hline T39. & $\begin{array}{l}\text { I can adapt the use of the technologies that I am learning about to different } \\
\text { teaching activities. }\end{array}$ \\
\hline T40. & $\begin{array}{l}\text { I can select technologies to use in my classroom that enhance what I teach, how I } \\
\text { teach and what students learn. }\end{array}$ \\
\hline T41. & $\begin{array}{l}\text { I can use strategies that combine content, technologies and teaching approaches } \\
\text { that I learned about in my coursework in my classroom. }\end{array}$ \\
\hline T42. & $\begin{array}{l}\text { I can provide leadership in helping others to coordinate the use of content, } \\
\text { technologies and teaching approaches at my school and/or district. }\end{array}$ \\
\hline T43. & I can choose technologies that enhance the content for a lesson. \\
\hline \multicolumn{2}{|r|}{ TPACK (Technology Pedagogy and Content Knowledge) } \\
\hline T44. & $\begin{array}{l}\text { I can teach lessons that appropriately combine mathematics, technologies and } \\
\text { teaching approaches. }\end{array}$ \\
\hline T45. & $\begin{array}{l}\text { I can teach lessons that appropriately combine literacy, technologies and teaching } \\
\text { approaches. }\end{array}$ \\
\hline T46. & $\begin{array}{l}\text { I can teach lessons that appropriately combine science, technologies and teaching } \\
\text { approaches. }\end{array}$ \\
\hline T47. & $\begin{array}{l}\text { I can teach lessons that appropriately combine social studies, technologies and } \\
\text { teaching approaches. }\end{array}$ \\
\hline
\end{tabular}

\section{References}

[1.] Vlada Republike Hrvatske, "Strategija obrazovanja, znanosti i tehnologije," Vlada Republike Hrvatske, 2014. [Online]. Available: http://www.azoo.hr/images/AZOO/Cjelovit_sadrzaj_Strategije_obrazovanj a_znanosti_i_tehnologije.pdf. [Accessed: May 8, 2017].

[2.] Agencija za odgoj i obrazovanje, "Strategija stručnog usavršavanja za profesionalni razvoj odgojno-obrazovnih radnika (2014-2020)," Agencija za odgoj i obrazovanje, 2014. [Online]. Available: http://www.azoo.hr/images/pkssuor/Dokumenti_hr.zip. [Accessed: May 7, 2017].

[3.] M. Koehler, and P. Mishra, "What Is Technological Pedagogical Content Knowledge?," Contemporary Issues in Technology and Teacher Education, vol. 9, no. 1, pp. 60-70, 2009.

[4.] OECD, "21st Century Learning: Research, Innovation and Policy (Directions from recent OECD analyses)," OECD, 2008. [Online]. Available: http://www.oecd.org/site/educeri21st/40554299.pdf. [Accessed: May 5, 2017].

[5.] European Commission, "The European qualifications framework for lifelong learning (EQF)," European Commission, 2008. [Online]. Available: http://ecahe.eu/w/images/3/34/EQF.pdf. [Accessed: May 5, 2017].

[6.] A. Drummond, and T. Sweeney, "Can an objective measure of technological pedagogical content knowledge (TPACK) supplement 
existing TPACK measures?," British Journal of Educational Technology, vol. 48, no.4, pp. 928-939, 2017.

[7.] D. A. Schmidt, E. Baran, A. D. Thompson, P. Mishra, M. J. Koehler, and T. S. Shin, "Technological Pedagogical Content Knowledge (TPACK)," Journal of Research on Technology in Education, vol. 42, no. 2, pp. 123149, 2009.

[8.] C. S. Chai, J. H. L. Koh, C.-C. Tsai, and L. L. W. Tan, "Modeling primary school pre-service teachers' Technological Pedagogical Content Knowledge (TPACK) for meaningful learning with information and Knowledge (TPACK) for meaningful learning with information and communication technology (ICT)," Computers \& Education, vol. 57, no. 1, pp. 1184-1193, 2011.

[9.] A. D. Ritzhaupt, A. C. Huggins-Manley, K. Ruggles, and M. Wilson, "Validation of the survey of pre-service teachers' knowledge of teaching and technology: A multi-institutional sample," Journal of Digital Learning in Teacher Education, vol. 32, no. 1, pp. 26-37, 2016.

[10.] C. C. Tsai, J. H. L. Koh, and C. S. Chai. "A Review of the Quantitative Measures of Technological Pedagogical Content Knowledge (TPACK)," in Handbook of technological pedagogical content knowledge (TPACK) for educators, M. C. Herring, M. J. Koehler and P. Mishra, Eds. Routledge, pp. 97-116, 2016.

[11.] J. M. Rosenberg, and M. J. Koehler, "Context and Technological Pedagogical Content Knowledge (TPACK): A Systematic Review," Journal of Research on Technology in Education, vol. 47, no. 3, pp. 186210, 2015.

[12.] Ministarstvo znanosti, obrazovanja i sporta, "Guide through the Croatian education system," Ministarstvo znanosti, obrazovanja i sporta, 2017. [Online]. Available: https://mzo.hr/sites/default/files/dokumenti/2017/OBRAZOVANJE/Nacion _manjine/Romi/engleski_dio_Romi/croatian_education_system.pdf. [Accessed: August 28, 2018].

[13.] UNESCO, “World Data on Education," UNESCO, 2006. [Online]. Available:

http://www.ibe.unesco.org/sites/default/files/United_States_of_America.pd f. [Accessed: August 28, 2018].

[14.] M. L. Niess, “Transforming Teachers' Knowledge: Learning Trajectories for Advancing Teacher Education for Teaching with Technology," in Technological Pedagogical Content Knowledge: Exploring, Developing, and Assessing TPCK, C. Angeli and N. Valanides, Eds. New York, Springer, pp. 19-37, 2014. 
[15.] M. J. Koehler, and P. Mishra, "What Happens When Teachers Design Educational Technology? The Development of Technological Pedagogical Content Knowledge," Journal of Educational Computing Research, vol. 32, no. 2, pp. 131-152, 2005.

[16.] S. N. Kushner Benson, C. L. Ward, and X. Liang, "The Essential Role of Pedagogical Knowledge in Technology Integration for Transformative Teaching and Learning," in Technological Pedagogical Content Knowledge: Exploring, Developing, and Assessing TPCK, , C. Angeli and N. Valanides, Eds. New York, Springer, pp. 3-19, 2015.

[17.] T. Valtonen, E. T. Sointu, K. Mäkitalo-Siegl, and J. Kukkonen, "Developing a TPACK measurement instrument for 21 st century preservice teachers," Seminar.net - International journal of media, technology and lifelong learning, vol. 11, no. 2, pp. 87-100, 2015.

[18.] J. Harris, M. Punya, and K. Matthew, "Teachers' Technological Pedagogical Content Knowledge and Learning Activity Types," Journal of Research on Technology in Education, vol. 41, no. 4, pp. 393-416, 2009.

[19.] M. J. Koehler, P. Mishra, K. Kerel, T. S. Shin, and C. R. Graham, "The Technological Pedagogical Content Knowledge Framework," in Handbook of Research on Educational Communications and Technology, M. J. Spector, M. D. Merrill, J. Elen, and M. J. Bishop, Eds. New York, Springer, pp. 101-111, 2014.

[20.] A. Drummond, and T. Sweeney, "Can an objective measure of technological pedagogical content knowledge (TPACK) supplement existing TPACK measures?," British Journal of Educational Technology, vol. 48, no.4, pp. 928-939, 2017.

[21.] I. Yurdakul, H. Odabasi, K. Kilicer, A. Coklar, G. Birinci, and A. Kurt, "The development, validity and reliability of TPACK-deep: a technological pedagogical content knowledge scale," Computers \& Education, vol. 58, no. 3, pp. 964-977, 2012.

[22.] L. M. Archambault, and J. H. Barnett, "Revisiting technological pedagogical content knowledge: Exploring the TPACK framework," Computers \& Education, vol. 55, no. 4, pp. 1656-1662, 2010.

[23.] P. Luik, T. Mere, and S. Reelika, "Perceptions of technological, pedagogical and content knowledge (TPACK) among pre-service teachers in Estonia," Education and Information Technologies, vol. 23, no. 2, pp. 741-755, 2018.

[24.] C. S. Chai, J. H. Koh, and C. C. Tsai, "Facilitating preservice teachers' development of technological, pedagogical, and content knowledge (TPACK)," Educational Technology and Society, vol. 13, no. 4, pp. 63-73, 2010 . 
[25.] J. Koh, C. Chai, and C. C. Tsai, "Examining the technological pedagogical content knowledge of Singapore preservice teachers with a large-scale survey," Journal of Computer Assisted Learning, vol. 26, no. 6, pp. 563$573,2010$.

[26.] M. H. Lee, and C. C. Tsai, “Exploring teachers' perceived self efficacy and technological pedagogical content knowledge with respect to educational use of the world wide web," Instructional Science, vol. 38, no. 1, pp. 1-21, 2010.

[27.] D. Baser, T. J. Kopcha, and M. Y. Ozden, “Developing a technological pedagogical content knowledge (TPACK) assessment for preservice teachers learning to teach English as a foreign language," Computer Assisted Language Learning, vol. 29, no. 4, pp. 749-764, 2015.

[28.] S. Pamuk, M. Ergun, R. Cakir, H. B. Yilmaz, and C. Ayas, "Exploring relationships among TPACK components and development of the TPACK instrument," Education and Information Technologies, vol. 20, no. 2, pp. 241-263, 2015.

[29.] V. H. Shinas, S. Yilmaz-Ozden, C. Mouza, R. Karchmer-Klein, and J. J. Glutting, "Examining Domains of Technological Pedagogical Content Knowledge Using Factor Analysis," Journal of Research on Technology in Education, vol. 45, no. 4, pp. 339-360, 2013.

[30.] J. Stevens, Applied multivariate statistics for the social sciences, 3rd ed., New York: Lawrence Erlbaum, 1996.

[31.] P. Kline, An -easy Guide to Factor Analysis, New York: Routledge, 1994.

[32.] D. N. Lewley, and A. E. Maxwell, Factor analysis as a statistical method., London: Butterworth and Co., 1971.

[33.] J. T. Abbitt, "Measuring Technological Pedagogical Content Knowledge in Preservice Teacher Education," Journal of Research on Technology in Education Preservice Teacher Education: A Review of Current Methods and Instruments, vol. 43, no. 4, pp. 281-300, 2011.

[34.] G. Norman, "Likert scales, levels of measurement and the 'laws' of statistics," Advances in Health Sciences Education, vol. 15, no. 5, pp. 625$632,2010$.

[35.] H. F. Kaiser, "The application of electronic computers to factor analysis," Educational and Pshychological Measurement, vol. 20, no. 1, pp. 141-151, 1960.

[36.] B. G. Tabachnick, and L. S. Fidell, Using Multivariate Statistics, Boston: Pearson, 2013. 
[37.] R. McDonald, and M.R. Ho, "Principles and Practice in Reporting Statistical Equation Analyses," Psychological Methods, vol. 7, no. 1, pp. 64-82, 2002.

[38.] S. Sharma, S. Mukherjee, A. Kumar, and W. R. Dillon, "A simulation study to investigate the use of cutoff values for assessing model fit in covariance structure models," Journal of Business Research, vol. 58, no. 1, pp. 935-943, 2005.

[39.] J. Miles, and M. Shevlin, "Effects of sample size, model specifications and factor loadings on the GFI in confirmatory factor analysis," Personality and Individual Differences, vol. 25, no. 1, pp. 85-90, 1998.

[40.] L. Hu, and P. Bentler, "Cutoff Criteria for Fit Indexes in Covariance Structure Analysis: Conventional Criteria Versus New Aternatives," Structural Equation Modeling, vol. 6, no. 1, pp. 1-55, 1999.

[41.] R. Kline, "Principles and Practice of Structural Equation Modeling," New York: The Guilford Press, 2005.

[42.] D. Hooper, J. Coughlan, and M. R. Mullen, "Structural Equation Modelling: Guidelines for Determinig Model Fit," Electronic Journal of Business Research Methods, vol. 6, no. 1, pp. 53-60, 2008. 